This is an author-produced PDF of an article published in The Asia-Pacific

Journal of Anthropology. Copyright Taylor \& Frances.

The definitive publisher-authenticated version is available online at:

http://www.tandfonline.com/doi/abs/10.1080/14442213.2013.866685

The citation information of that definitive version is:

Grant, C. (2014). Perspectives of culture-bearers on the vitality, viability and

value of traditional Khmer music genres in contemporary Cambodia. The Asia-

Pacific Journal of Anthropology 15(1), 26-46. Doi:

$10.1080 / 14442213.2013 .866685$

\title{
Perspectives of culture-bearers on the vitality, viability and value of traditional Khmer music genres in contemporary Cambodia
}

\section{Abstract}

Previous studies have explored the historical and social context for the endangerment and subsequent revitalization of Cambodian performing arts, but little work has focused on music, or the views of culture-bearers themselves on these issues. By thematically analysing qualitative data from semi-structured interviews conducted in early 2013, this research explores the perspectives and motivations of a group of master-musicians, teachers and performers who are making efforts to sustain and revive their music traditions. Participants emphasised five factors that they believed significantly interplayed with the vitality of traditional Khmer music genres. Four of these were generally perceived to have an overall adverse effect on vitality: 'outside' influence; loss of interest and knowledge among younger people; low market demand for performances and teaching; perpetuation of limiting constructs and belief systems. Only one factor identified was perceived to have a beneficial effect on vitality: the strength of infrastructure for learning and teaching. Somewhat surprisingly, then, opinions about the viability of traditional genres were on aggregate highly optimistic, though with some concern expressed about the impact of government action (and inaction) on this issue. Justifications given for sustaining and revitalising traditional Khmer genres included the role of these traditions in education and ritual, Cambodian national identity, and musicians' livelihoods. The study confirms the perceived value, among one group of culture-bearers, of revitalizing Khmer music traditions.

Keywords: Cambodian music; Khmer music; intangible cultural heritage; cultural revitalisation; cultural sustainability; traditional music 


\section{Introduction}

Not all the trouble with the current state of Cambodia's performing arts can be attributed to the ongoing effects of the Khmer Rouge era, but much of it can. No aspect of Cambodian society - education, economy, healthcare, culture, religion was left undisrupted during that time (1975-1979), and music was no exception. Traditional genres ${ }^{1}$ were condemned as counter-revolutionary, and banned (Gorton, 1989), and all other music functioned solely as political propaganda. Instrumentbuilding workshops were closed down, and traditional instruments were neglected or destroyed (Loban, 1990). With the closure of the University of Fine Arts in 1975, and with family units rent apart in the genocide, all familial and institutional mechanisms for the transmission of traditional music were broken. According to some estimates, over half of all Cambodian performance traditions were lost completely during these years (Visiting Arts, 2001, p. 25). The human toll was far worse still, and among the millions who lost their lives during Pol Pot's devastating rule of Democratic Kampuchea (as the country was then known) were an estimated 90 per cent of musicians and other artists, specific targets of the Khmer Rouge regime.

With its primary aim to establish a classless, agrarian, communist state, the Khmer Rouge set out to abolish money, private property, free markets, usual schooling, public transportation, religion, traditional culture, foreign influence, public gatherings, and non-revolutionary entertainment. Cities were evacuated; schools, universities, temples, factories, shops and government buildings were closed down, their buildings often turned into prisons, re-education camps, or grain store-houses. Those considered unfit to contribute to the agrarian ideal - including intellectuals, bureaucrats, politicians, teachers, skilled workers, people from minority groups, musicians, dancers, and other artists - were killed. The Cambodian Genocide Project at Yale University (2010) estimates that over $20 \%$ of the population (1.7 million people) died during the Khmer Rouge regime, due to execution, starvation, inhumane treatment, and lack of medical care.

\footnotetext{
1 While traditional is a highly contested term in ethnomusicological circles (Schippers, 2010, pp. 41-47 discusses the issues), the designation traditional music is arguably relatively clear in Cambodia, since cross-cultural, mediatised, digitised influences did not significantly interplay with local music genres until the late 1990s or early 2000s. In 1998, Sam, Roongruang and Nguyễn still wrote of a "fundamental division" between traditional and modern music in Cambodia (pp. 155-156). When I use the term traditional in this paper in relation to Khmer music genres, I am referring to 'heritage' genres from before the Khmer Rouge era (without intending to imply that the manifestations of these genres 'before' and 'after' this era are, or should be, identical).
} 
By the 1980s, the deep-seated effects of the Khmer Rouge era on the musical culture of Cambodia were becoming evident. The notable decline in the quality of performing artists was attributed to the death of most master-artists and the length of time taken to train new recruits (Chheng Phon in Sam, S-A, 1990), as well as the inability of remaining musicians to practice their art due to the physical and mental repercussions of forced labour, malnutrition, and trauma. Nevertheless, according to several accounts, the process of cultural recovery and regeneration began almost immediately once the Khmer Rouge fell from power. The re-opening in early 1981 of the University of Fine Arts, with a music faculty teaching both traditional Khmer and Western classical music, was a significant step. Miller suggests that the arts were the first aspects of Cambodian culture to be restored, and that cultural restoration itself in many ways preceded the physical rebuilding of the country (in Sam \& Campbell, 1991).

That rebuilding, however, has been slow, difficult and incompletely documented. Selected recent studies do provide in-depth accounts of the regeneration of certain cultural practices: Zucker (2006) explores the ambiguous attempts of one village community to find ways to re-connect to a pre-Khmer Rouge past through the revival of a traditional harvest festival; Marston (2006) examines revival of ritual practices through the case of the veneration of a Buddhist monk's deceased body; and Diamond (2003) explores the challenges to the renewal of Cambodian theatre. Turnbull (2006) provides a broader entrée into the recent history and contested present of Cambodian performing arts, and several further papers in Ollier and Winter's edited volume Expressions of Cambodia (2006) examine the revival of tradition and heritage.

This research builds on these studies to advance the understanding of the perceived position, function, and trajectory of traditional music genres in particular, and the performing arts more generally, in contemporary Cambodia. The paper examines the personal motivations, experiences, and opinions of master-musicians, performers and teachers on the current vitality and future prospects of these (and other) traditional music genres, and their reasons for engaging in efforts to revitalise them. In this way, this study contributes to a body of academic research into Cambodian performing arts that is relatively sparse, in no small part due to the difficulties involved with data collection in the country in the 1970s and 1980s and 
the preoccupation in subsequent decades with security, nation-building, and the reform of political and economic institutions.

\section{Traditional music in contemporary Cambodia}

The traditional importance of music in all facets of $\mathrm{Khmer}^{2}$ society is welldocumented. Bas relief images of musicians playing instruments adorn the monuments of Angkor. In the thirteenth century, the Chinese envoy Zhou Daguan recorded the presence of musicians in court and life-cycle festivities (Zhou trans. Harris, 2007). The Khmer royal court was a major sponsor of the arts, and musicians and musical ensembles featured in ceremonies and rituals, forming a prominent part of the pageantry of court life. In popular culture and village contexts, music was an indispensible component of communal festivals held in local temples to mark seasonal transitions and propitiate and thank the spirits of the land. Music was also central to the conduct of life-cycle rituals; an array of specific musical instruments, genres and forms were used in weddings, funerals, Buddhist rites and other such lifecycle events to guarantee their efficacy and auspiciousness. Groslier (1965), Sam, Roongruang and Nguyễn (1998) and UNESCO (2003b) provide detailed information about traditional Cambodian genres and instruments, and their social functions and contexts.

The five genres most referred to in this article - pinn peat, pleng kar buran, kantaoming, smot, and chape $i^{3}$ - serve to illustrate some of these traditional contexts and functions for Cambodian music genres, as well as their current social positioning. Pinn peat refers to both an ensemble of instruments and a genre, and traditionally has been used in a range of celebratory and ceremonial functions, including as an accompaniment for court dance, religious events, royal occasions, and shadow puppet theatre sbek thom (see Figure 1). The term pinn peat refers to both the genre and the ensemble of instruments that plays it. It is the most well known of Khmer traditional genres, both within Cambodia and abroad. In contemporary contexts pinn peat ensembles can be seen and heard in local temple festivals and are featured in

\footnotetext{
2 Once used exclusively to describe the dominant ethnic group in the nation of Cambodia (and the language of this people), the term Khmer is now often used to refer to the people of Cambodia more generally, including members of the minority groups who reside there. In this paper, Khmer is used in the narrower sense, since the music traditions I refer to all belong to the dominant ethnic group. 3 There is a general lack of consistency in the Romanisation of Khmer words. In this article I take advice on spellings from my research participants and the available literature.
} 
television programs, video clips, and in performances for tourists in hotel and restaurants.

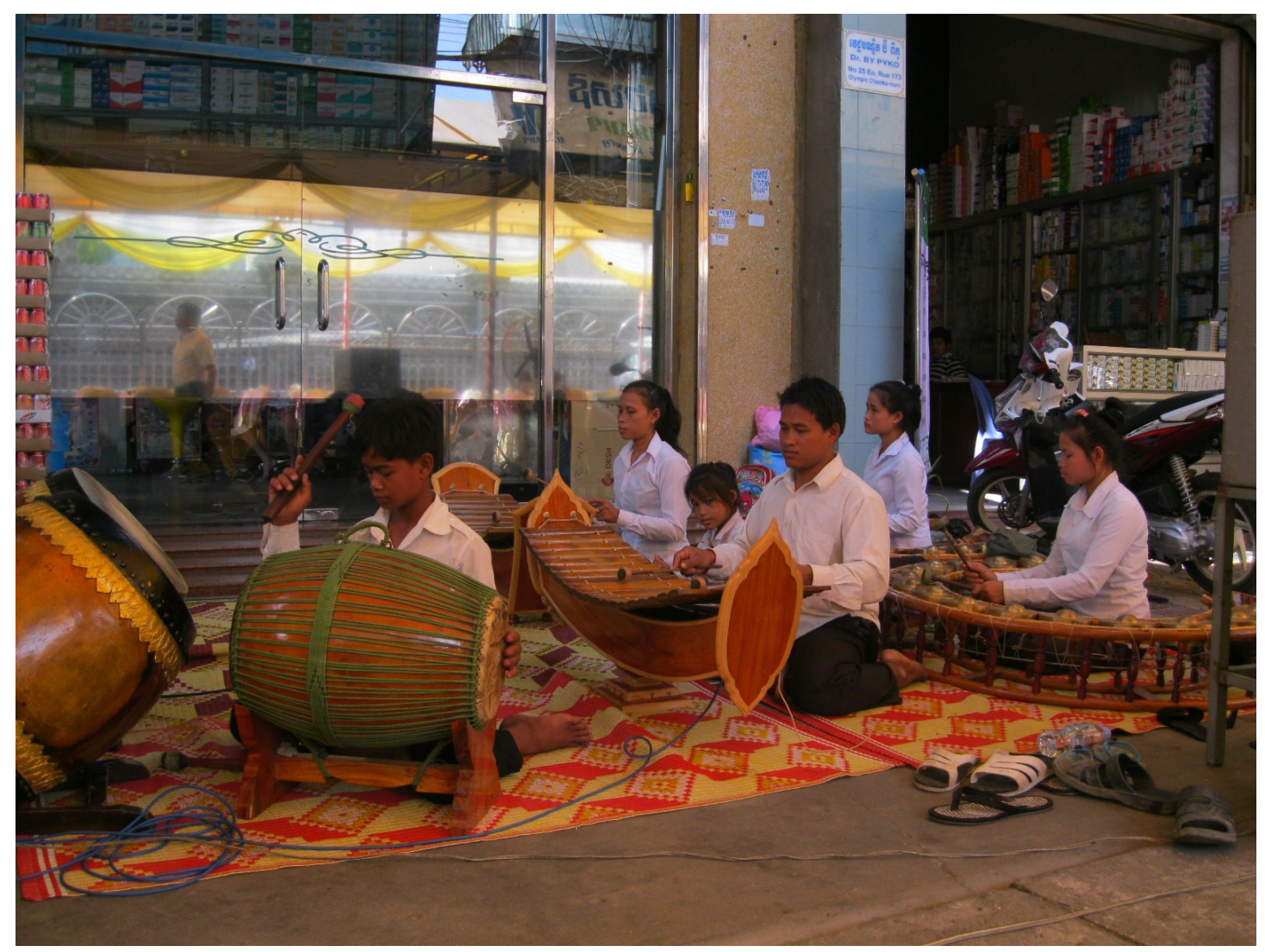

Figure 1. Pinn peat ensemble rehearses on a street sidewalk for a wedding. Phnom Penh, 5 February 2013. Photo by the author.

Two further ensemble genres with more specific functions are pleng kar buran (or vung phleng kar) (Figure 2), used in wedding ceremonies, and kantaoming (also kontoaming or kantoam ming) (Figure 3), historically performed at each stage of the funeral rite to guide the spirit of the deceased into the afterlife (Sam, Roongruang \& Nguyễn, 1998). These ensembles are typically slightly smaller than a pinn peat ensemble, with perhaps six to eight players, though this can vary depending on availability of instruments and performers. Both once widely used in village ceremonies, these genres are generally now only found in one or two provinces; kantaoming particularly is very rare. Also associated with death and dying is smot (or smaut), a form of Buddhist chant sung in Pali and typically heard in private healing or cremation ceremonies or monastic contexts (Figure 4). 


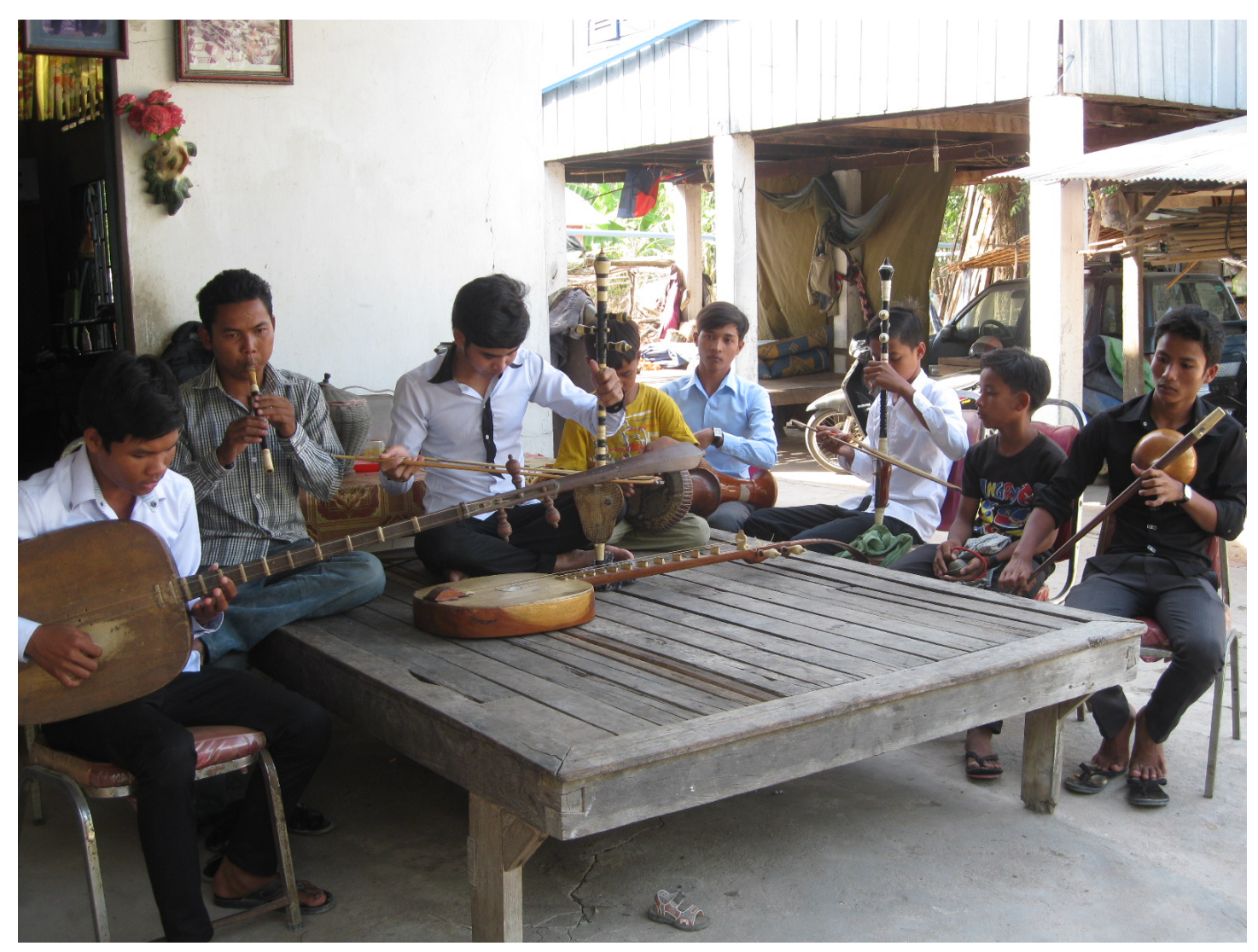

Figure 2. Students in the pleng kar buran class of master-musician Sok Duch rehearse outside his home in Takeo Province, 22 February 2013. A chapei is on the far left. Photo by the author. 


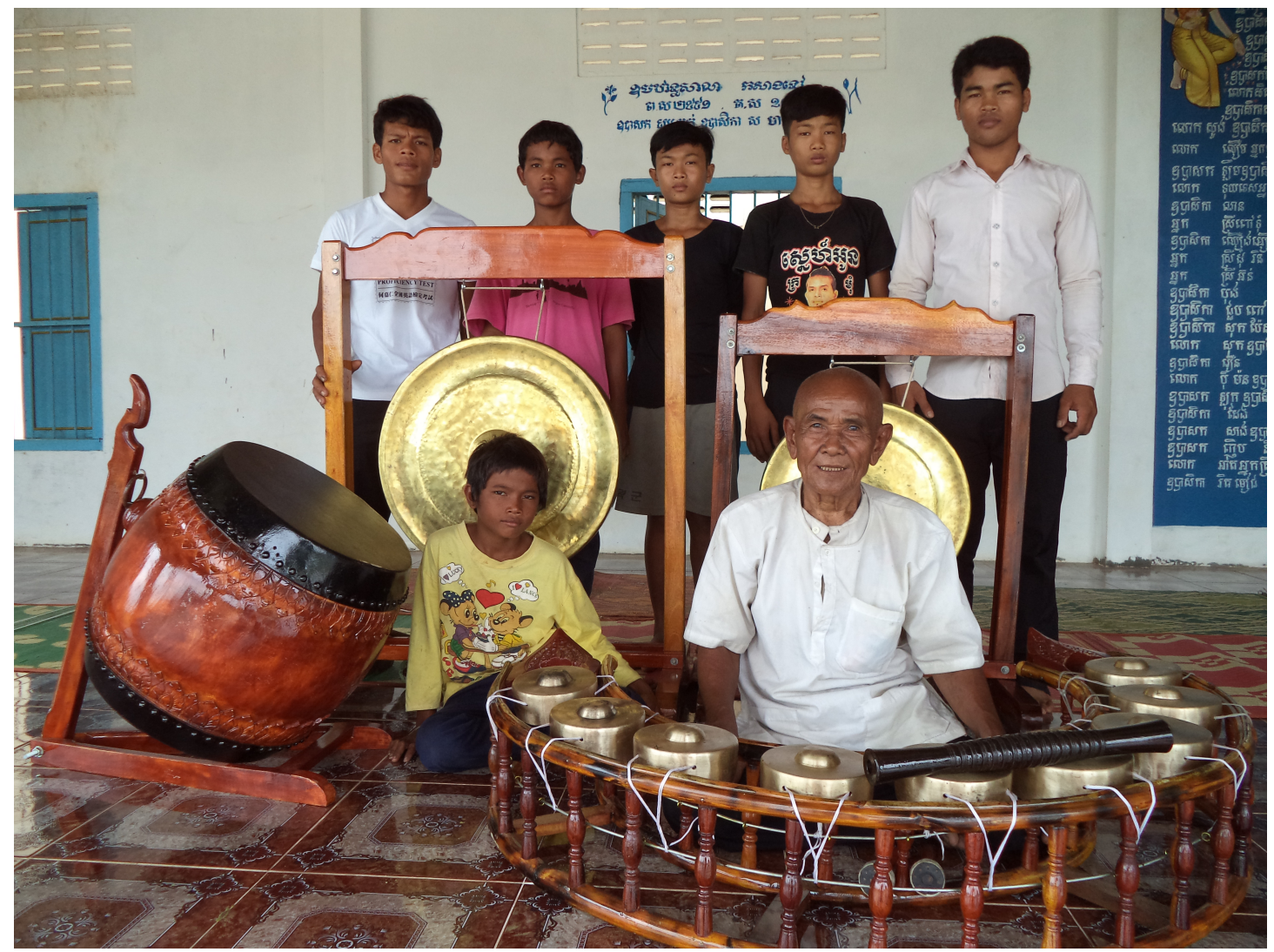

Figure 3. Master-musician Seng Norn with students and instruments of the kantaoming ensemble. This new set of instruments was purchased in July 2013 with funds raised from a crowdfunding campaign run by the author (see www.pozible.com.au/lastlivingmaster). Photo: Sopheak Sun, August 2013. 


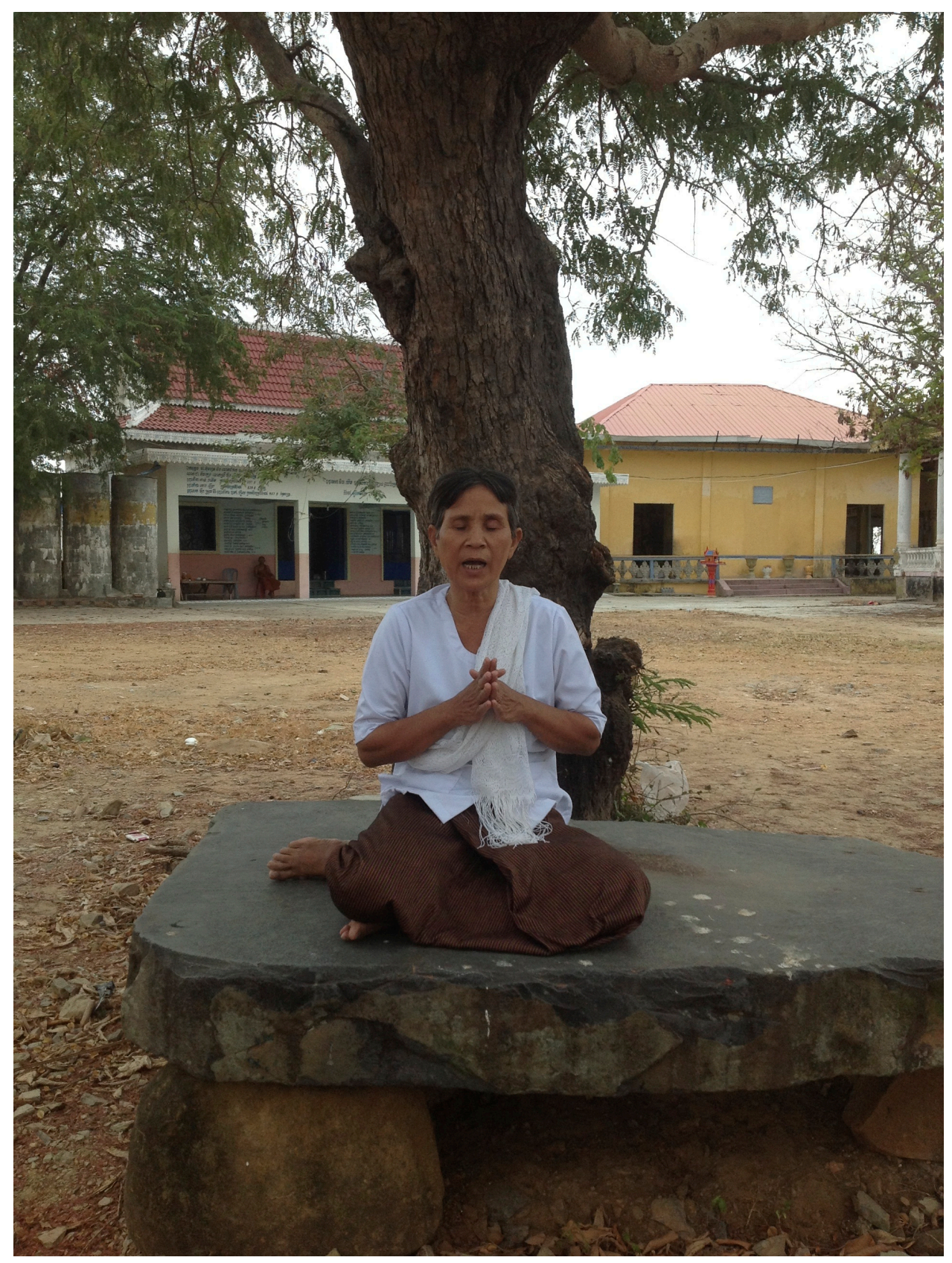

Figure 4. Smot teacher Keot Ran chants smot on temple grounds in Kampong Speu province. Photo by the author, 22 February 2013.

Finally, the instrument chapei (or chapey), short for chapei dong weng (also chapey dang veng), or 'long-necked lute', is used sometimes in ensembles, but is most familiar through the genre chrieng chapei ('epic singing'), in which the player sings and where both words and music are improvised (Figure 5). A short-necked chapei was once in existence, but is used no longer. Individual chapei players improvising songs sometimes can be seen in areas frequented by tourists in downtown Phnom Penh. The instrument and epic song form have been popularised 
internationally by the blind player-singer Kong Nay, who has been on many international tours and has featured in documentaries and radio programs. In this way, chrieng chapei is one of the few Cambodian genres to have found a place within the international ambit of 'world music', where it is often known by the (somewhat misleading) moniker 'Mekong Delta Blues'.

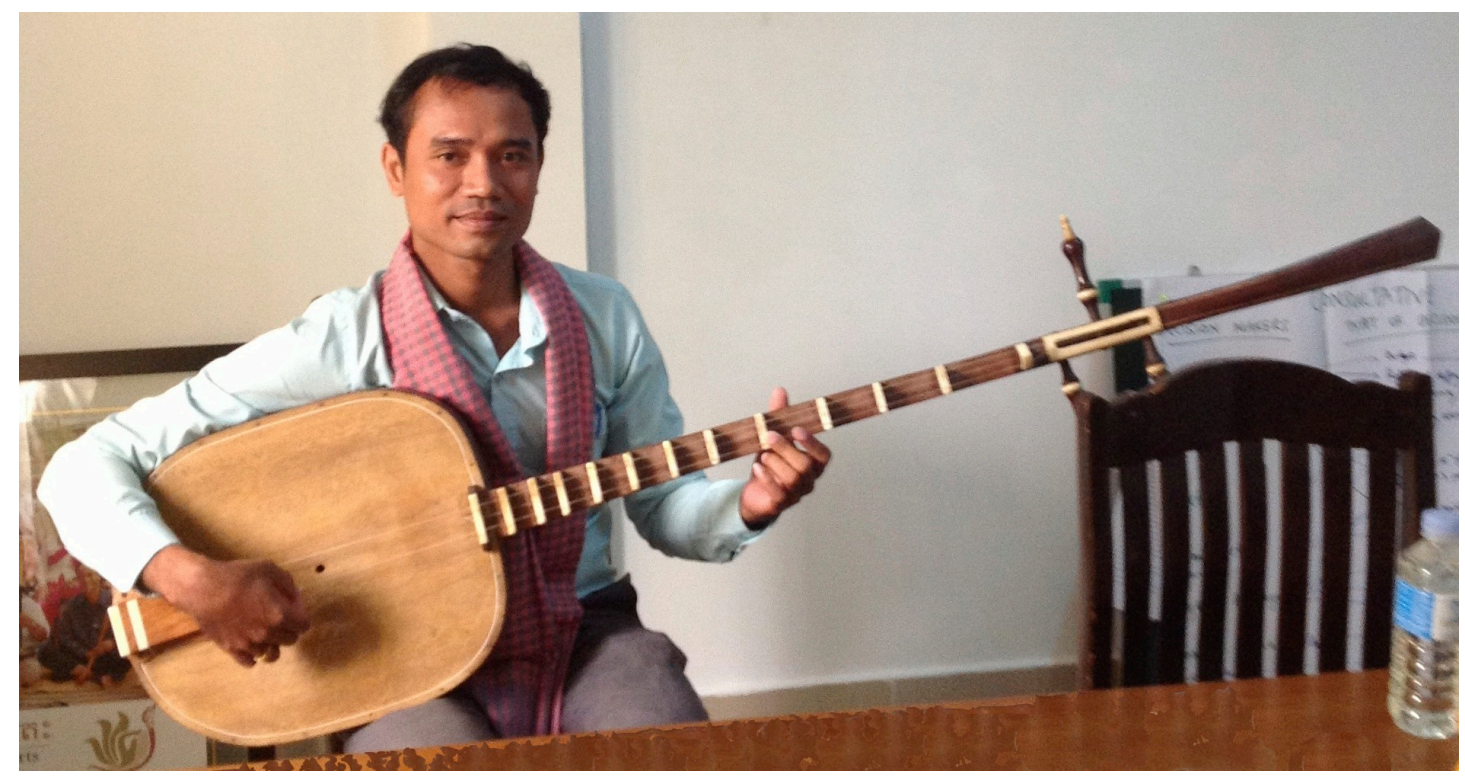

Figure 5. Chapei teacher Pich Sarath with chapei dong weng. Phnom Penh offices of Cambodian Living Arts. Photo by the author, 21 February 2013.

The challenges facing these five music genres (and other traditional genres) go beyond the daunting task of recovering from the damage inflicted to them during the period the Khmer Rouge were in power. In common with many traditional genres in other countries of the region, Cambodian traditional music faces contemporary threats to its survival brought about by rapid social and technological change, urbanisation and globalisation (Taylor, 2003; Douglas, 2009). Organisations such as UNESCO have sounded the alarm about the danger posed to indigenous musical forms across the world, including from Western pop music and globalised youth culture.

Nevertheless, predictions that traditional music might be swept away in the processes of globalisation and modernisation are complicated by the resurgence in some regions and countries of rituals and customary practices, giving employment and increased prominence to traditional musicians (Norton, 2009). Scholars have noted the key role of musical performance in defining national identity and, conversely, "the influence of national-level politics on shaping music expression" (Castro, 2011). Ritual and charisma remain central to certain classical music performances in neighbouring 
Thailand and Vietnam, indicating that the commodification of tradition, brought about for example by tourism or cultural heritage promotion, does not necessarily lead to diminution of the sacred dimensions of music traditions (Wong, 2001; Cannon, 2013).

In Cambodia, although the desire to revitalise traditional music genres appears to be strong (particularly among the government, culture-bearers, and youth), translating this desire into successful revitalisation strategies has proven a difficult task. Despite the current government's ideological support of the arts (under Prime Minister Hun Sen), it is probably small wonder that the cultural sector is not its highest priority: the basic needs of almost half the population are not yet met. A high rural poverty rate, poor access to health services and education, income inequality, gender disparity, low government capacity, political corruption, poor legal and financial infrastructure, high domestic violence rates, poor living conditions and lack of basic services (Um, 2011) restrict the lives of many of the 14.5 million Cambodians. $80 \%$ of the population live outside the urban areas, and $45.9 \%$ of all Cambodians suffer from multiple deprivations at the individual level in terms of health, education and standard of living (UNDESA, 2012a). In 2012, the life expectancy at birth was just 63.6 years (admittedly an improvement from 55.6 in 1990; UNDESA, 2012b).

Nevertheless, some significant steps have been taken at this level to promote and protect Cambodia's arts and culture, including engaging with UNESCO's various intangible cultural heritage safeguarding programs and activities. In 2008, sbek thom (shadow puppet theatre) and Royal Ballet of Cambodia (Khmer classical dance) were inscribed on the UNESCO Representative List of the Intangible Cultural Heritage of Humanity; a couple of years later, the Royal Decree on Living Human Treasures was signed, and as of early 2013, seventeen masters had been recognized with this title. Considerable governmental efforts are also being made to document and inventory Cambodian intangible cultural heritage, through the Ministry of Culture and Fine Arts. Despite these activities, a proportion of this heritage still faces a very uncertain future. UNESCO itself believes many Cambodian cultural forms remain "in danger of disappearing", attributing this mainly to "long-lasting conflicts, the declining number of performers and the clear tendency among the younger generation to cultural influences from outside the country" (2013). 
Along with government, another key player in cultural revitalisation efforts is the non-profit sector, with a number of non-government organisations engaging in cultural regeneration efforts. One of the most vibrant is Cambodian Living Arts (CLA; www.cambodianlivingarts.org), based in Phnom Penh and an initiative of the Marion Institute in the USA. It implements a series of programs aiming to support the transmission and revitalisation of traditional Cambodian performing arts, build local capacity, and foster sustainability for performers and performance genres by creating arts-related employment opportunities and promoting awareness of the arts both within Cambodia and abroad (see Figure 6). By providing master-musicians ${ }^{4}$ with a salary and medical benefits, its transmission program supports the transfer of musical knowledge and skills to younger people. For many musicians, the lack of such support would render it unfeasible to devote significant time to artistic practices because of the imperative to earn a living; especially in villages and rural areas, generating sufficient income from performances and teaching is very challenging.

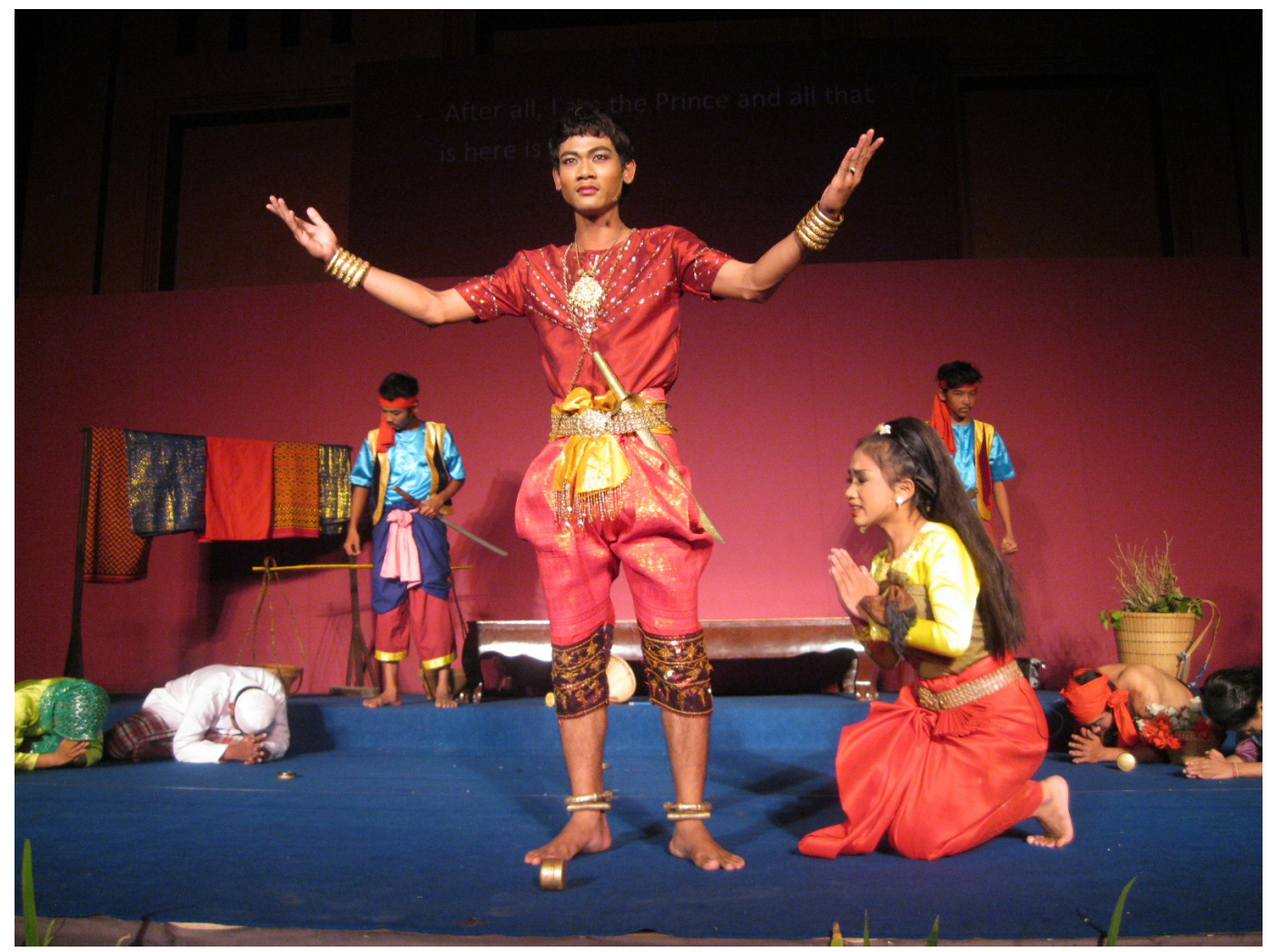

\footnotetext{
${ }^{4}$ In keeping with the local practice of those interviewed for my research, the terms master-musician and master-artist are reserved for those individuals who learnt and practiced their art before the Khmer Rouge era; other instructors are referred to as teachers. Many master-artists are now in their sixties and seventies - or even eighties, though with national average life expectancy as it is, these individuals are very few.
} 


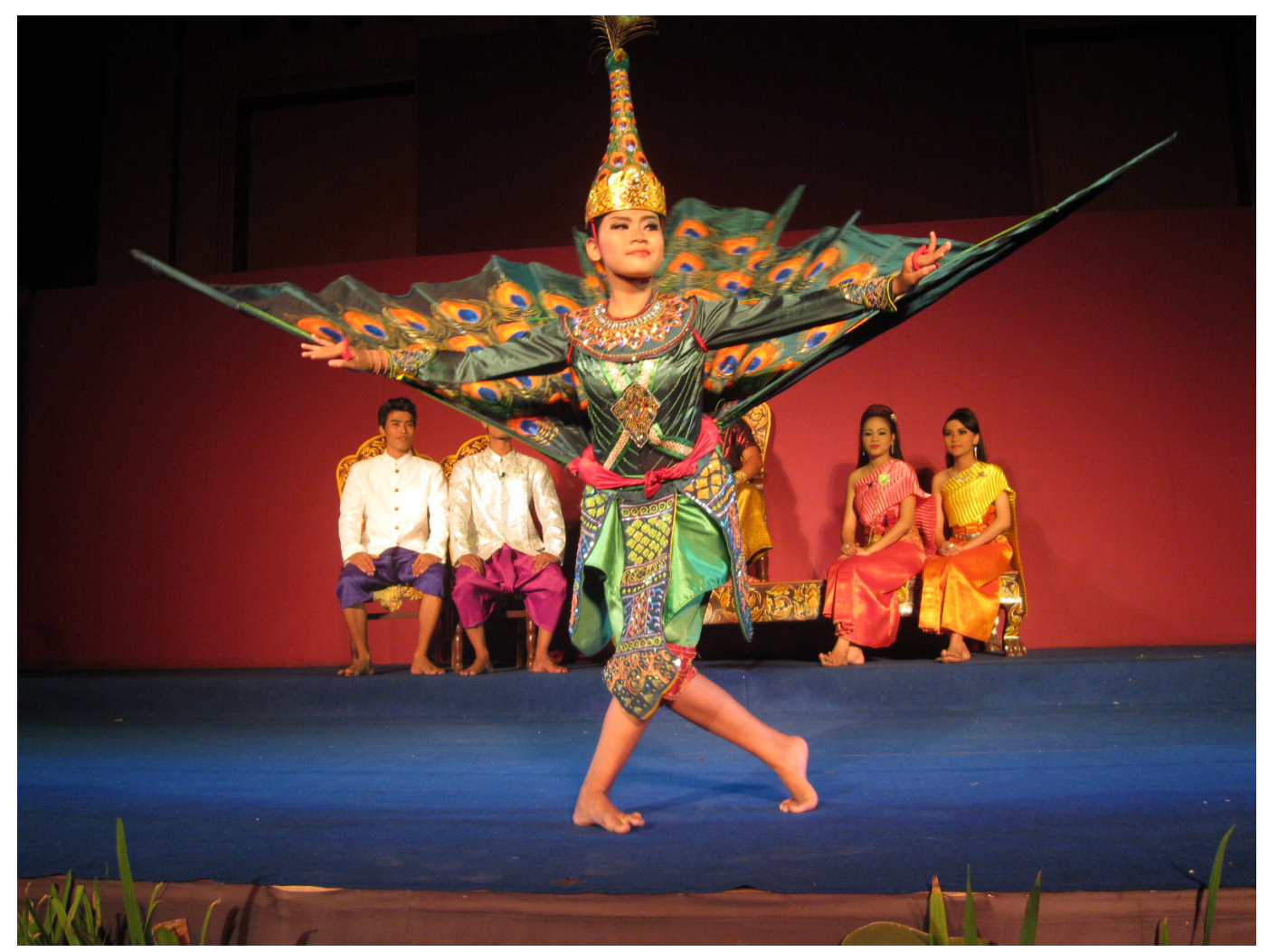

Figures $6 a$ and 6b. Performance of yike opera piece Mak Therng at the National Museum in Phnom Penh, a part of Cambodian Living Arts' ongoing “Plae Pakaa” performance series. Photo by the author, 23 February 2013.

While CLA and other non-profit organisations have certainly boosted the number of people learning and teaching traditional performing arts genres, and have created new opportunities for artists including performances for tourists and tours abroad, these activities necessarily impact on transmission and performance practices in complex ways. During a sbek thom (shadow puppet theatre) rehearsal on temple grounds in Siem Riep one balmy evening in early 2013 (see Figure 7), I was witness to one event that highlighted the contentiousness of this impact. A highly-respected elderly monk, who had come to oversee the rehearsal, interrupted proceedings in annoyance as the narrator began to also play a role traditionally designated to a second narrator. The rehearsal stopped for 20 minutes or more as an animated discussion took place between the monk and those directing and performing the work. I learnt later that the decision to conflate the two narrator roles had been made at least partly in order to save the cost of an airfare for an upcoming CLA-run tour of the troupe to Indonesia. Issues like these - relating to tradition and innovation and their interconnection with changing and often global contemporary contexts for music 
genres - are common throughout the world, and recur as themes in the literature on music sustainability and change (Grant, in press). A full critique of the role and impact (positive and negative) of NGOs in cultural maintenance and revitalization in Cambodia is beyond the scope of this paper, but is explored in some depth in other studies (e.g. Diamond, 2003; Hodal, 2012).

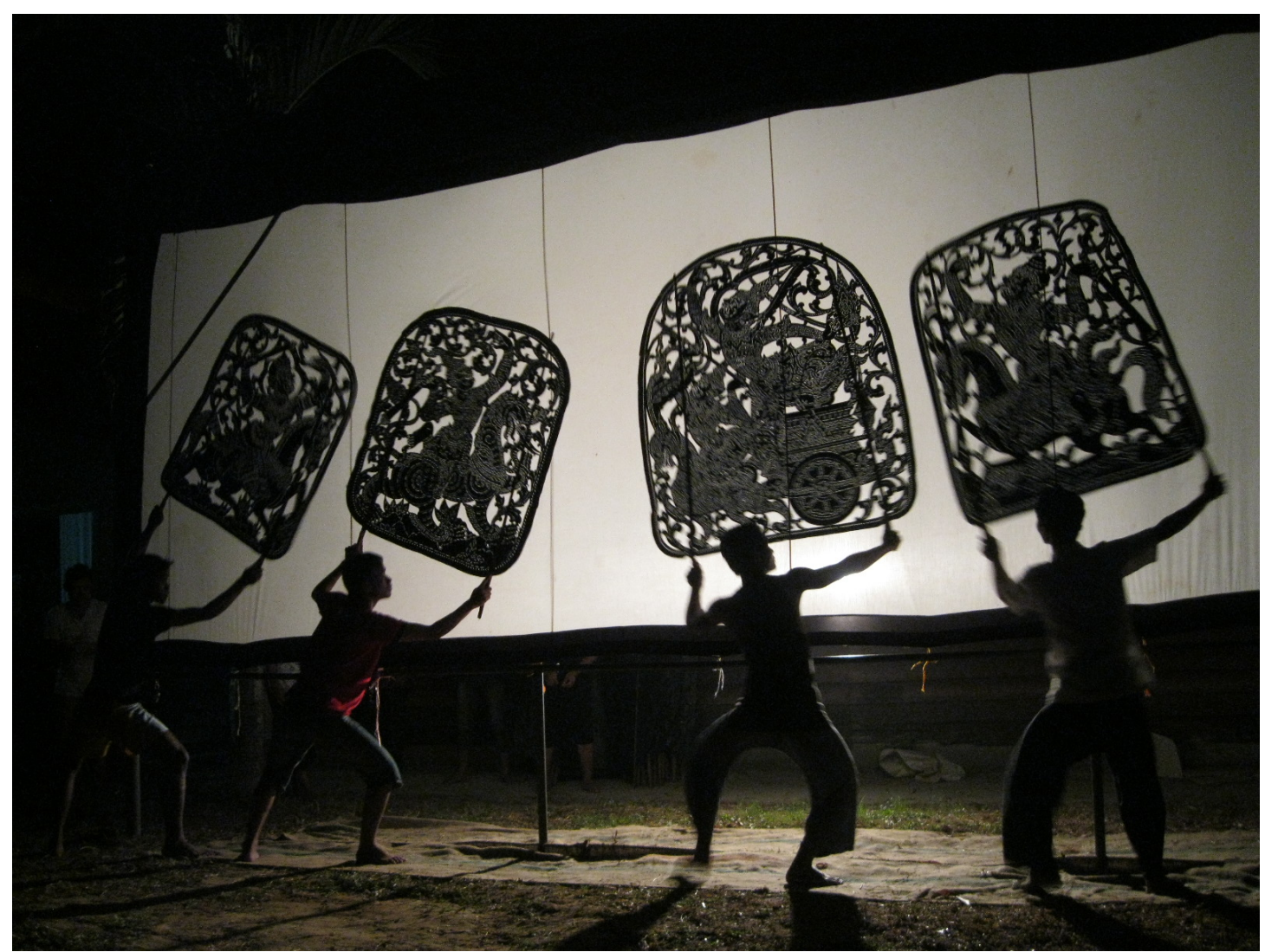

Figure 7. Sbek Thom (shadow puppet theatre) rehearsal of a student troupe organised by Cambodian Living Arts. Wat Bo, Siem Riep, 10 February 2013. Photo by the author.

The data for this study were gathered through a series of semi-structured interviews with master-musicians, teachers and performers during a field trip in early 2013, as well as my own field notes and observations, and a review of the literature. The ten interview participants were recruited with the assistance of Cambodian Living Arts, and all had some current or former involvement in its cultural heritage preservation, teaching and outreach programs. They included three master-musicians, and seven other musicians who teach, perform, or do both. (Figure 8 shows the locations of interviews across the four provinces of Siem Riep, Kampong Speu, Takeo, and Phnom Penh; Appendix 1 provides further participant information.) 


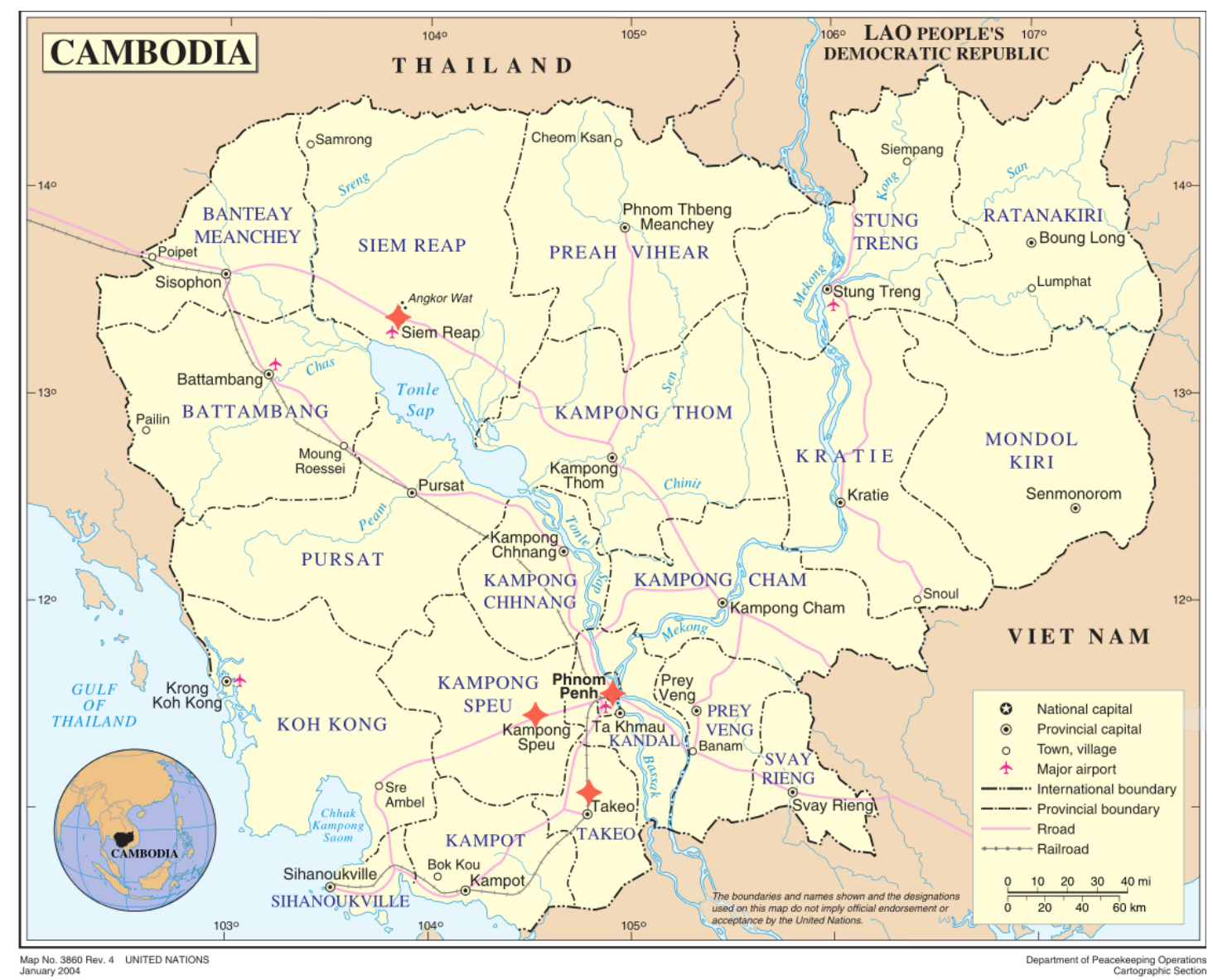

Figure 8. Location of interviews (Cambodia). Map under Creative Commons Licence from www.worldofmaps.net

While the study does not offer the textured ethnographic insights that come from long-term immersion and participation in musical practice, its approach does give prominence to considerations of voice and experience that have come to the fore in recent ethnomusicology (Barz \& Cooley, 1997). Given the somewhat restrictive political situation, the difficult and painful recent national history, and the fact that my broad research topic (cultural regeneration) implies this history, the interviews admittedly only provide one account of social reality that is dependent on what, and how much, a participant chooses to reveal (Jenkins, 2002). Triangulating data from other sources mitigates this issue to some extent, but not completely.

Interviews centred on participants' perspectives on the value of revitalising Cambodian performing arts, both to the participants themselves and more broadly to society. During interviews, participants spoke in Khmer with immediate English interpretation (and opportunity for clarification). Thematic coding and analysis of the 
English transcripts drew on a general inductive approach (Thomas, 2006). Key themes fell into three broad and related topics: participants' views on (1) the current level of vitality of Cambodian traditional music genres; (2) the future prospects of these genres; and (3) rationales for maintaining or revitalising them.

\section{Music vitality}

Interview participants placed emphasis on five factors that they believed significantly interplayed with the vitality of traditional Khmer music genres. In four of these five cases, the overall impact on vitality was perceived to be adverse.

The first of these factors was 'outside' influence on traditional Khmer music practices, a phenomenon related to the growing 'mediaisation' of music in Cambodia (Malm, 1993) and more broadly to processes of globalisation and modernisation. One can easily detect the appetite for foreign music among Cambodian youth in the mushrooming of music video programs, discos, and karaoke clubs playing music performed by Cambodian singers influenced by foreign music, performers and styles. Interview participants generally viewed the change in music practices resulting from these processes as undesirable, and reflected UNESCO's statement (mentioned earlier) that 'outside' cultural influences are placing traditional Cambodian cultural forms at risk (2013). As I chatted with elderly master-musician Sok Duch outside his home in Takeo Province, the mega-hit Gangnam Style (by South Korean artist Psy) blared away from the street, prompting his reflection: "Some of the Cambodian pop singers copy some traditions from neighbouring countries, and I feel ashamed of being Cambodian, because [they] Cambodian but [they] sing like that". Another master-musician, Man Men, felt that "modern music spoils the young generation a lot. I think it comes from other countries . . . and then they come to Cambodia and it spoils the tradition, so it's not good".

A second factor identified as affecting vitality was a loss of interest and knowledge about the traditions and their related cultural features, particularly among the younger generation. Of the wedding music genre pleng kar boran, Man Men reflected: "Pol Pot destroyed this art form, and now the young generation have been forgetting [it] and don't really want to know [about it]". He attributed the lack of interest in traditional music genres among younger people at least partly to influences from outside Cambodia. Iem Vichet, 26-year-old teacher of pinn peat, felt that a lack 
of cultural knowledge among members of the younger generation inhibits their appreciation of, and therefore interest in, that tradition:

Not so many people want to learn the shadow puppets, and also not many young people understand the story of the Ramayana ... But the old people are more interested because they know the story and then they understand the puppets when they play. Now young people watch a lot of TV shows, and puppets are not that interesting any more.

Lack of knowledge was also a concern in relation to the now rare genre kantaoming. Due to the scarcity of ensembles, recordings are now often used in lieu of live performance. Even so, a lack of knowledge affects the practice of the tradition, as master-musician Seng Norn describes:

The people who play it [the recording] don't really know when they should play this song, when they should play that song. It is different if you have the real troupe, the live troupe: they will know exactly when they should play, what they should play. ... When they [use a] recording, they mostly don't know which song they should play.

Third, some participants considered the low market demand for performances of traditional genres to be a key inhibitor of musical vitality. For Yim Chanty, minimal opportunities to play and perform the woodwind instruments snaeng (buffalo horn), pei pok (free-reed pipe) and pei or (double-reed pipe) has led to a demise in her performance skills: "If you do it every day you get better, but if you leave it out, it's a vicious circle: you don't have the market, you don't perform; you don't perform, you're degrading [your skills]". The lack of popularity of these instruments undoubtedly has more than one cause. Music researcher and instrument-maker Yim Chot suggests that the restricted opportunities for performing the snaeng, for example, arise partly from its specific uses in ritual, which traditionally included attracting wild elephants during hunting expeditions, and invoking spirit possession of a tranced medium in the arakk ceremony (Sam, Roongruang \& Nguyễn, 1998, p. 205) - in short, "you're not going to learn it to be able to perform on stage" (Yim Chot). Conversely, the greater demand for khloy (flute) performances and teaching leads Yim Chanty to feel she plays this instrument best of all, because her skills are constantly in use. The ongoing relative popularity of the khloy may be due to the fact that it is "easy to learn" and "looks nicer" than other instruments (Yim Chot); over 
two decades ago, Sam and Campbell attributed the fact at least in part to the accessibility of bamboo used to make it (1991, p. 41).

A fourth factor identified by participants as central to the current vitality of traditional genres is the constructs and belief systems that surround them. The association of kantaoming with death, for example, made community members reluctant to allow Seng Norn to teach the genre within earshot of their homes; he eventually negotiated a venue for his classes in a wat (temple) at sufficient distance from the township. When asked about the popularity of chapei in Cambodia, Pich Sarath replied that only those people over about 30 years of age still like to listen to the genre, but even this demographic doesn't like to play the chapei instrument, because there is a belief that if you study chapei, you tend to become blind. Even some people who met me - they are not that old, maybe 35,36 - said to me, 'Why do you study chapei? Are you not afraid of becoming blind?' Although Pich Sarath himself doesn't believe that learning the instrument poses a threat to him in this way (saying it was "a co-incidence" that many chapei players were blind in the pre-Khmer Rouge era), the ongoing association with blindness in the popular opinion continues to adversely affect the vitality of the tradition.

Contrasting with these four (perceived) unfavourable factors in vitality, several participants commented that the systems in place for learning and teaching Khmer genres were making a crucial and positive contribution to their vitality. Man Men, for example, was grateful to non-profit organisation CLA for providing him with teaching incentives (in the form of a salary, medical support, and general recognition):

During my generation there were six artists who could play pleng kar buran like me, but were killed [during the Khmer Rouge era]. Now I can teach about 25 to 30 students in a class, supported by Cambodian Living Arts, which is working to make this classical wedding music alive and [to] support me, support my class.

While likewise expressing appreciation of the support structures in place through CLA, the last remaining actively-teaching master of kantaoming Seng Norn voiced a feeling of isolation in his efforts to maintain the vitality of the genre: "it seems like only I am trying so hard to keep it alive". 


\section{Music viability}

Perhaps surprisingly given the perspectives on the current vitality of traditional Khmer music genres described above, opinions about their viability were on the whole highly optimistic. For teacher Iem Vichet, the regular airing of pinn peat on local television and its heightened live presence in some rural areas in recent years signal a positive trajectory for his art form: "I can tell that in the future there will be a lot of people who know and like to learn pinn peat". He expressed his hope, "as a young man, ... that pinn peat can play with other instruments on the international stage, that they can perform more broadly, more widely". With regard to chapei, teacher Pich Sarath was also hopeful that the tradition would increase in popularity, though only with continued efforts to clear the belief that studying chapei causes blindness.

Perspectives on viability were positive among older-generation participants too. Before becoming involved with the transmission programs of Cambodian Living Arts, Keot Ran thought that the tradition of smot chanting could be lost altogether, "but after CLA came to support me to teach, I realised that now we have the supporters, and I'm quite confident that we can continue this form". Man Men believes that associations like CLA will help sustain and revitalise pleng kar boran, leading eventually to its greater recognition and promotion. Sok Duch once feared that Khmer music genres might fade away, but the recent efforts of some younger people to learn, along with a wider public recognition of the traditions (including airtime on TV and radio), brings him hope. For kantaoming, Seng Norn trusts that "it will be better in the future":

I think if we continue like now, try to keep kantaoming alive, when I'm gone I believe it will be exposed more to the public, and they will have more interest in kantaoming art form.

Several participants believed governmental support could play an important role in supporting the vitality and viability of Khmer traditional music, and more than one expressed reservations about the effectiveness and satisfactoriness of current ongoing government interventions (specifically those of the Ministry of Arts and Culture) to protect and promote cultural heritage ${ }^{5}$. One expressed the belief that

\footnotetext{
5 This paragraph in particular and the research at large should be understood in the political context in which it is situated, in which not everything that is felt or thought can be articulated. I choose to
} 
despite his own substantial efforts in teaching his skills to his students, the sustainability of his tradition ultimately relies on "other parties, the play-makers in society, maybe the government agency for arts and culture, to provide [my students] the opportunity to practice more their skills". Thus, this participant explained,

If you ask me if I'm optimistic or not [about the future of my genre], I think that depends on the government. If the government takes action, maybe we can make the instruments, the art form, our arts and culture famous again.

\section{Rationales for music revitalisation efforts}

Participants gave three main justifications for making efforts to sustain and revitalise traditional Khmer music genres: for social reasons, specifically the role of these genres in education and rites; for reasons of reconstructing and strengthening Khmer (and Cambodian) identity; and for economic reasons.

In the case of kantaoming, Seng Norn believes the ongoing viability of the genre is "very important for the whole society", because:

kantaoming is the only music that can be played when your soul leaves your body, and it's very important that this music helps your soul rest in peace. . . . [The deceased] need the music to [reach] a place where they can find peace when they leave the earth.

The Buddhist Khmer chanting smot is also mainly heard at funerals, where it comforts the bereaved; it may also serve to comfort the dying. Its integral function in end-oflife rites leads Keot Ran to believe "it is who we are and it is attached to what we are doing", and for this reason it is important to protect and promote it. Iem Vichet places value on the social function of ceremonial ensemble genre pinn peat, which is used "in almost any traditional celebration. . . . If it's lost, it would be very bad and a very big loss . . because pinn peat is in a lot of society, so it would be the loss of soul".

Certain Khmer music traditions also play an educational function, and some participants indicated that this strongly justified efforts to support and revitalise them. The improvised lyrics in the chapei tradition, for example, are intended to transmit an educational message in addition to entertaining the listener. Thus, for Pich Sarath, "the chapei has its unique place in that sense. ... We should be proud of it and not let it die". Educational function was also important for teacher Keot Ran, who described 
the importance of maintaining smot partly in terms of its social utility as described above, and partly in terms of its role in perpetuating the teachings of the Buddha in contemporary Cambodia.

The second reason for participants placing value on maintaining and revitalising traditional genres was the potential role of these genres in reinforcing Khmer and/or Cambodian (national) identity. Performer Phan Chamroeun, proficient on a number of instruments across several traditional genres, expressed openness towards musical adaption, experimentation and innovation, yet believed that keeping the "original" forms was important because they "show the identity of Khmer - the Khmer arts, the Khmer culture". Keot Ran felt it was important to keep smot strong because it's "a Khmer tradition, because if you look at what you do at funerals, you do the smot chanting; so this is our tradition, our culture, of being Khmer". When asked why he makes efforts to teach traditional genres, Sok Duch replied in terms of a unique national identity:

I think it's important for the whole nation, the whole society, because it's like an identity for the nation. ... In my opinion, I think [these genres are] purely classical, purely Cambodian ... So that's why. . . . It shows the identity of Cambodia.

On this issue, some participants referred specifically to the importance of rebuilding national identity in the wake of Cambodia's tragic recent history. Mastermusician Man Men identified this to be the main reason he strives to pass on his knowledge of the classical wedding genre pleng kar boran:

The art is the soul of the nation. If the art is destroyed, the nation will also be destroyed, as you can see when the war happened and when Pol Pot came. They didn't really have even relations, they didn't have culture, they didn't have a nation. So that's why [I teach]. All the country was destroyed because they didn't really have the soul of art, the soul of the nation in their minds. Yun Theara (Yun Khean) reflected a similar philosophy (implying the country's recent history) with the comment: "If the culture disappears, the nation also disappears". In his view, robust knowledge, understanding and practice in Cambodian society of local arts and culture is essential, since this acts as a barrier to undue cultural influence from outside: "If a container is full of water, no other water can go into the container; but if that container is only half-full, then some other water can 
easily come in. ... The strength of a nation is dependent on the arts". Again, issues of identity are core.

Several participants also referred to the potential modest economic gain from learning and performing traditional genres, and in a country of Cambodia's economic circumstances, this in itself is surely a fair reason to create sustainable opportunities to learn and perform. For Seng Norn, for example, kantaoming is important because in addition to its social function, "[it] can be a job ... While [the troupe members] are playing they can earn some finances to support their family". Yim Chanty believes that financial gain is nowadays a decisive factor in young people's choice of which instrument to learn. Income prospects were indeed a key driver in Pich Sarath's decision to focus on the chapei, and most of his ten students (ranging in age from late teens to around 40 years old) are "poor people" who "want to earn some money through learning chapei". The potential to generate a modest income from playing or performing exists for musicians of most, if not all, genres described in this paper.

\section{Conclusions}

This study is an initial exploration, with a small number of musician-participants, on the perceived vitality, viability, and importance of maintaining and revitalising traditional Khmer music genres. The participants were all involved in traditionalmusic activities in some capacity, suggesting that those genres already held some value to them. The majority had access to infrastructure and resources to carry out their teaching and/or performing activities, many through the support of Cambodian Living Arts. This is obviously not the case for many other teachers and performers in Cambodia; musicians without such support are likely to have different experiences from those presented in this study, and may also have different values around issues of cultural revitalisation. Also, other interpretations of the interview data are no doubt possible, and for this reason, ample quotes have been provided above to enable the reader to draw conclusions that differ from those I offer.

Internationally, a growing body of work underscores the importance to individuals, communities, and nations of protecting and promoting intangible cultural heritage, including for reasons of social and cultural identity, economic benefit, and health and wellbeing outcomes (UNESCO, 2003). With the ongoing consequences of the Khmer Rouge era forming a palpable undercurrent to participants' responses, this study revealed a prudent perspective on the current vitality of traditional genres, a 
comparatively optimistic perspective on their future viability, and a firm resolve that these traditions should not pass away. The importance to participants of regenerating and revitalising Cambodia's music traditions was framed in terms of social cohesion, national and cultural identity, economic development, and notably, fear of further disruption to lives and culture through lack of cultural - and therefore and political strength in the future. Understanding these perspectives may help sensitise researchers to the uniqueness and ongoing challenges of cultural revitalization in the post-war Cambodian state and society.

\section{Acknowledgements}

My thanks firstly to the master-musicians, teachers and performers who participated in this study. I am humbled by your gentle strength. Many thanks also to Chap Vithur, independent consultant to Cambodian Living Arts (CLA), and Sopheak Sun, project co-ordinator for CLA in Siem Riep, for interpreting and helping to check permissions; to CLA Program Director Frances Rudgard for organisational assistance; and to all the staff and students at CLA for your warm hospitality during my stay. I greatly appreciate the helpful suggestions and input to this article by two anonymous reviewers and the editor of this journal, Dr Philip Taylor.

\section{Appendix 1: Interview participants}

\begin{tabular}{|c|c|c|c|c|c|}
\hline $\begin{array}{l}\text { Interview location / } \\
\text { date }\end{array}$ & $\begin{array}{l}\text { Name of } \\
\text { participant }\end{array}$ & Gender & Age & Genre & Further information \\
\hline $\begin{array}{l}\text { Wat Bo grounds, Siem } \\
\text { Riep. } 11 / 2 / 13 \text {. }\end{array}$ & Iem Vichet & $\mathrm{M}$ & 26 & Pinn peat & $\begin{array}{l}\text { Teacher, student and } \\
\text { performer }\end{array}$ \\
\hline $\begin{array}{l}\text { Wat grounds, } \\
\text { Kampong Speu } \\
\text { province. } 22 / 2 / 13 \text {. }\end{array}$ & Keot Ran & $\mathrm{F}$ & 60 & Smot & Teacher and performer \\
\hline $\begin{array}{l}\text { Wat Bo grounds, Siem } \\
\text { Riep. 11/2/13. }\end{array}$ & Man Men & $\mathrm{M}$ & 65 & $\begin{array}{l}\text { Pleng kar } \\
\text { boran }\end{array}$ & Master \\
\hline $\begin{array}{l}\text { CLA offices, Phnom } \\
\text { Penh. 21/2/13. }\end{array}$ & $\begin{array}{l}\text { Phan } \\
\text { Chamroeun }\end{array}$ & $\mathrm{M}$ & 21 & $\begin{array}{l}\text { Tro sau, sralai } \\
\text { (genres: } \\
\text { mahori, pinn } \\
\text { peat) }\end{array}$ & Performer and student \\
\hline $\begin{array}{l}\text { CLA offices, Phnom } \\
\text { Penh. } 21 / 2 / 13 \text {. }\end{array}$ & Pich Sarath & $\mathrm{M}$ & 29 & Chapei & Teacher and performer \\
\hline $\begin{array}{l}\text { Wat Bo grounds, Siem } \\
\text { Riep. } 11 / 2 / 13 \text {. }\end{array}$ & Seng Norn & $\mathrm{M}$ & 72 & Kantaoming & Master \\
\hline $\begin{array}{l}\text { Outside interviewee's } \\
\text { home, Samrong Torng } \\
\text { village, Bati district } \\
\text { Takeo province. } \\
22 / 2 / 13 \text {. }\end{array}$ & Sok Duch & $\mathrm{M}$ & 87 & $\begin{array}{l}\text { Pleng kar } \\
\text { boran }\end{array}$ & Master \\
\hline $\begin{array}{l}\text { CLA offices, Phnom } \\
\text { Penh. 21/2/13. }\end{array}$ & Yim Chot & $\mathrm{M}$ & 48 & $\begin{array}{l}\text { Wind } \\
\text { instruments }\end{array}$ & $\begin{array}{l}\text { Writer for Department of } \\
\text { Cultural Development } \\
\text { (Ministry of Culture), }\end{array}$ \\
\hline
\end{tabular}




\begin{tabular}{|l|l|l|l|l|l|}
\hline & & & & & $\begin{array}{l}\text { instrument-maker, } \\
\text { (amateur) performer }\end{array}$ \\
\hline $\begin{array}{l}\text { CLA offices, Phnom } \\
\text { Penh. 21/2/13. }\end{array}$ & Yim Chanty & $\mathrm{F}$ & 45 & $\begin{array}{l}\text { Wind } \\
\text { instruments }\end{array}$ & Performer \\
\hline $\begin{array}{l}\text { CLA offices, Phnom } \\
\text { Penh. 21/2/13. }\end{array}$ & $\begin{array}{l}\text { Yun Theara } \\
\text { (Yun Khean) }\end{array}$ & $\mathrm{M}$ & 55 & Various & $\begin{array}{l}\text { Performer; works for } \\
\text { Ministry of Culture }\end{array}$ \\
\hline
\end{tabular}

Note: gender representation is broadly indicative of the lower number of female versus male masters and teachers generally (largely for social reasons which are beyond the scope of this paper to explore).

\section{References}

Apsara Arts Association (n.d.). Website. Retrieved 30 March, 2013, from http://www.apsaraart.org/htm/about-aaa.html

Bader, Rolf (n.d.). Buddhism, animism, and entertainment in Cambodian melismatic chanting smot: History and tonal system. Retrieved 7 February, 2013, from http://systmuwi.de/muwi_research_Comparative_Musicology_Cambodia.html

Barz, Gregory \& Cooley, Timothy (Eds.) (1997). Shadows in the field: New perspectives for fieldwork in ethnomusicology. Oxford University Press.

Cambodia Tribunal Monitor (2013). Website. Retrieved 27 September, 2013, from http://www.cambodiatribunal.org/history/cambodian-history/khmer-rouge-history/

Cambodian Genocide Program, Yale University (2010). Website. Retrieved 27 September, 2013, from http://www.yale.edu/cgp/

Cambodian Living Arts (CLA) (2013). Website. Retrieved 24 April, 2013, from http://www.cambodianlivingarts.org

Cannon, Alexander (2013). When charisma sustains tradition: Deploying musical competence in Southern Vietnam, Ethnomusicology 57(1), 88-115.

Castro, Christi-Anne (2011). Musical renderings of the Philippine nation. Oxford University Press.

Cultural Survival (1990a). Cambodia [Special edition]. Cultural Survival Quarterly 14(3). Retrieved 3 February 2013 from http://www.culturalsurvival.org/publications/cultural-survival-quarterly/143-fall1990-cambodia

Cultural Survival (1990b). Flowers in the forest: A talk with Chheng Phon, Minister of Information and Culture. Cultural Survival Quarterly 14(3). Retrieved 3 February 2013 from http://www.culturalsurvival.org/publications/cultural-survival- 
quarterly/cambodia/flowers-forest-talk-chheng-phon-minister-informati

Diamond, Catherine (2003). Emptying the sea by the bucketful: The dilemma in Cambodian theatre. Asian Theatre Journal, 20(2), 147-178.

Douglas, Gavin (2009). Music in mainland Southeast Asia. Oxford University Press.

Dutt, Nidhi (n.d.). Cambodians revive traditional arts scene. Retrieved 20 January 2013, from http://australianetwork.com/focus/s3541404.htm

Ear, S. (2010). Khmer Rouge tribunal vs. karmic justice. New York Times, March 17, 2010 [online version]. Retrieved 24 April, 2013, from http://www.nytimes.com/2010/03/18/opinion/18iht-edear.html

Ellison, M. (1985). Consciousness of poverty in black music. Popular Music and Society, $10(2), 17-46$

Glatzer, Jocelyn (Director) (2003). The flute player [documentary film]. Boston, MA: Over the Moon Productions.

Gorton, Philip. (1989, Nov 12). Artistic revival flowers after long drought of oppression. The Gazette. Retrieved 22 January 2013 from Proquest database.

Grant, C. (2014, in press). Music endangerment: How language maintenance can help. New York: Oxford University Press.

Groslier, Bernard-Philippe (1965). Danse et musique sous les Rois d'Angkor. In Felicitation Volumes of Southeast Asian Studies, Presented to His Highness Prince Dhaninivat Kromamun Bidyalabh Bridhyakorn, 283-292. Bangkok: The Siam Society.

Hodal, K. (2012, Mar 29). The art of survival. The Guardian. Retrieved 22 January 2013 from Proquest database.

Jenkins, R. 2002. Pierre Bourdieu (revised ed.). Abingdon: Routledge.

Ledgerwood, J. (1990). A building full of books. Cultural Survival Quarterly 14(3). Retrieved 30 March 2013 from http://www.culturalsurvival.org/publications/culturalsurvival-quarterly/cambodia/court-ballet-cambodias-loveliest-jewel

Loban, W. (1990). Making the traditional musical instruments of Cambodia. Cultural Survival Quarterly 14(3). Retrieved 3 February 2013 from http://www.culturalsurvival.org/ourpublications/csq/article/making-traditionalmusical-instruments-cambodia

Malm, Krister (1992). Local, national and international musics: A changing scene of interaction. In M. P. Bauman (Ed.), World music, musics of the world: Aspects of 
documentation, mass media and acculturation, 211-217. Wilhemshaven: Florian Noetzel.

Miller, Terry E. (1980a). Cambodia: Traditional Music by Chinary Ung [Review]. Ethnomusicology, 24(1), 141-142. Retrieved 19 January 2013 from http://www.jstor.org/stable/851329

Miller, Terry E. (1980b). Cambodia: Traditional Music by Chinary Ung [Review]. Ethnomusicology, 24(2), 333-335. Retrieved 19 January 2013 from http://www.jstor.org/stable/851139

Morton, David (1974). Cambodia; Folk and Ceremonial Music by Jacques Brunet [Review]. Ethnomusicology, 18(3), 471. Retrieved 22 January 2013 from http://www.jstor.org/stable/850535

Nelson, Roger (2012). Non-profit art spaces in Cambodia: Strength in diversity. Art Monthly Australia, 253, 22-24.

Norton, Barley (2009). Songs for the spirits: Music and mediums in modern Vietnam. Champaign, IL: University of Illinois Press.

Norton, S. (2005). Homrong: Classical music from Cambodia by Pete Reiniger; Chum Ngek; Joanna Pecore [review]. Yearbook for Traditional Music 37, 187-188. Retrieved 19 January 2013 from http://www.jstor.org/stable/20464957

Ollier, Leakthina Chau-Pech \& Winter, Tim (Eds). (2006). Expressions of Cambodia: The politics of tradition, identity, and change. Abingdon, Oxon: Routledge.

Sam, Chan Moly (1990). Returning to Cambodia: Khmer artists seek growth. Cultural Survival Quarterly 14(3). Retrieved 30 March 2013 from http://www.culturalsurvival.org/ourpublications/csq/article/returning-cambodiakhmer-artists-seek-growth

Sam, Sam-Ang (1990). Preserving a cultural tradition: Ten years after the Khmer Rouge. Cultural Survival Quarterly 14(3). Retrieved 30 March 2013 from http://www.culturalsurvival.org/publications/cultural-survivalquarterly/cambodia/preserving-cultural-tradition-ten-years-after-khme

Sam, Sam-Ang \& Campbell, Patricia (1991). Silent temples, songful hearts: Traditional music of Cambodia. Danbury, CT: World Music Press.

Sam, Sam-Ang, Roongruang, Panya \& Nguyễn, Phong T. (1998). The Khmer people. In Miller, Terry (Ed.), Garland Encyclopedia of World Music Vol. 4: Southeast Asia. Retrieved 26 April 2013, from Alexander Street database. 
Schippers, H. (2010). Facing the music: Shaping music education from a global perspective. New York: Oxford University Press.

Springer, George P. (1965). UNESCO Collection--A Musical Anthology of the Orient by Alain Danielou [LP Review]. Ethnomusicology, 9(3), 337-340. Retrieved 19 January 2013 from http://www.jstor.org/stable/850254 .

Taylor, Philip (2003). Digesting reform: Opera and cultural identity in Ho Chi Minh City. In Lisa Drummond \& Mandy Thomas, (Eds)., Consuming urban culture in contemporary Vietnam, 138-154. London: RoutledgeCurzon.

Thomas, D. R. (2006). A general inductive approach for analyzing qualitative evaluation data. American Journal of Evaluation, 27, 237-246.

Titon, Jeff Todd (Ed.). (2009). World of Music [Special issue: Music and Sustainability], 51(1). Bamberg: Department of Ethnomusicology, Otto-Friedrich-University.

Tully, John (2005). A short history of Cambodia: From empire to survival. Crows Nest, NSW: Allen \& Unwin.

Turnbull, Robert (2005). A burned-out theater: The state of Cambodia's performing arts. In Ollier, Leakthina Chau-Pech \& Winter, Tim (Eds) (2006). Expressions of Cambodia: The politics of tradition, identity, and change, 133-149. Abingdon, Oxon: Routledge.

Um, Khatharya. (2011). Cambodia: Hopes, trials, and tribulations. Southeast Asian Affairs (2011), 53-70. Retrieved 22 January 2013 from Proquest database.

UNDESA (2012a). International Human Development Indicators: Cambodia. Retrieved 23 April, 2013, from http://hdrstats.undp.org/en/countries/profiles/KHM.html

UNDESA (2012b). 2010 revision of world population prospects. Retrieved 15 April 2013, from http://hdrstats.undp.org/en/indicators/69206.html

UNESCO (2003a). Convention for the Safeguarding of Intangible Cultural Heritage.

Retrieved 18 May, 2013, from http://portal.unesco.org/en/ev.phpURL_ID $=17716 \& U R L \_D O=D O \_T O P I C \& U R L \_S E C T I O N=201 . h t m l$

UNESCO (2003b). Traditional musical instruments of Cambodia $\left(2^{\text {nd }}\right.$ ed.). Retrieved 26 April, 2013, from unesdoc.unesco.org/images/0013/001352/135257mb.pdf UNESCO (2008). The establishment of Living Human Treasures system in the Kingdom of Cambodia: Final narrative project report. Phnom Penh: UNESCO Office in Phnom Penh / Ministry of Culture and Fine Arts.

UNESCO (2013). Cambodia: Intangible Cultural Heritage [website]. Retrieved 24 April, 2013, from http://www.unesco.org/culture/ich/en/state/kh 
Ung, Chinary (compiler) (1979). Cambodia: Traditional Music, Vol. 2. [LP]. Folkways FE 4082.

Ung, Loung (2000). First they killed my father: A daughter of Cambodia remembers. New York: Harper Collins.

Visiting Arts (2001). South East Asia Regional Arts Profile: Cambodia Arts Directory. London: Visiting Arts.

Wellington, J. (2000). Educational research: Contemporary issues and practical approaches. London: Continuum.

Winter, T. \& Ollier, L.C-P. (2006). Introduction: Cambodia and the politics of tradition, identity and change. In Ollier, Leakthina Chau-Pech \& Winter, Tim (Eds) (2006). Expressions of Cambodia: The politics of tradition, identity, and change, 1-19. Abingdon, Oxon: Routledge.

Wong, Deborah (2001). Sounding the center: History and aesthetics in Thai Buddhist ritual. Chicago University Press.

Zhou Daguan [Trans. Harris, Peter] (2007). A record of Cambodia: The land and its people. Chiang Mai: Silkworm Press.

Zucker, Eve M. (2006). Transcending time and terror: The re-emergence of Bon Dalien after Pol Pot and thirty years of civil war. Journal of Southeast Asian Studies 37(3), 527546. Retrieved 26 April 2013 from Expanded Academic ASAP. 